\title{
Away from fossil-fuels and toward a bioeconomy: Knowledge versatility for public policy?
}

\section{Farhad Mukhtarov}

Utrecht University, Copernicus Institute of Sustainable Development; and

National University of Singapore, Lee Kuan Yew School of Public Policy, Singapore

\section{Andrea Gerlak}

School of Geography and Development and Udall Center for Studies in Public Policy

at the University of Arizona, USA

\section{Robin Pierce}

Brunel University London, School of Law, London, UK

\begin{abstract}
In the face of energy security and climate change, and with technological advances, many industrial countries have embraced the transition to a bioeconomy - an economy based on energy, chemicals and materials obtained from biomass. However, the policy and academic discourses on a bioeconomy transition suggest growing controversy around its social, environmental and ethical impacts. In this article, we apply an epistemic forms framework to better understand the scope and extent of the bioeconomy debate. We find that industry and governments take a narrow approach to a bioeconomy and tend to view it exclusively as a technical concept. We argue that the discursive and practical dimensions of the transition would shed light on the issues of what type of a bioeconomy to strive for, through which procedures and with what impacts for diverse stakeholders. We conclude with a set of recommendations related to a bioeconomy transition.
\end{abstract}

\section{Keywords}

Bioeconomy, epistemic forms, policy-makers, transition management

\section{Introduction}

Governments and industry around the world pay increasing attention to a bioeconomy amid increasing concerns over energy security, looming climate change and the promise of economic benefits of new technologies. A bioeconomy has been discussed in Europe since

\section{Corresponding author:}

Farhad Mukhtarov, Universiteit Utrecht Faculteit Geesteswetenschappen, Utrecht, the Netherlands.

Email: fmukhtarov@gmail.com 
the 2005 publication of the European Commission Framework Programme-7 research agenda (Directorate General Research, 2006; Langeveld et al., 2010).

One definition of a bioeconomy depicts it as an 'economy using biological resources from the land and sea as well as waste, including food wastes, as inputs to industry and energy production' (European Commission, 2012a). We treat such terms as 'bioeconomy', 'bio-economy', 'bio-based economy', 'bio-based society', and 'knowledge-based bioeconomy' as synonymous (McCormick and Kautto, 2013; Paula and Birrer, 2006; Scarlat et al., 2015). We approach a bioeconomy as a socio-technological transition which can be defined as 'a gradual continuous process of change when the structural character of a society (or complex subsystems of society) is transformed' (Dewulf et al., 2009: 27). Transitions are characterized by systemic changes in modes of production and consumption, accompanied by changes in beliefs, values and governance (Kern and Smith, 2008).

One aim of this article is to explore how various actors constitute and discuss a bioeconomy. We apply the epistemic forms framework to evaluate the diversity of knowledge claims in public and policy debates, including scientific, value-based and practical forms of knowledge. We argue that in the pursuit of such a large-scale socio-technological transition, both policy and public discourses need to reflect knowledge versatility. The second aim of this article is to characterize the major policy challenges in steering a bioeconomy transition, and provide recommendations for policy-makers and scholars to facilitate this transition. Although many actors contribute to the steering of complex socio-technological transitions, we focus on policy-makers, in a generic and not country-specific context, as they can play a leading role in structuring such steering. We agree with Loorbach and Rotmans (2005: 5) who argue that 'transitions. . . can be managed in terms of influencing and adjusting' and are interested in how policy-makers at multiple levels can shape the bioeconomy transition by supporting democratic and participatory processes. Finally, we attempt to offer broader implications of epistemic pluralism for public policy scholarship and future research.

This examination begins with a review of the policy and academic discourses on a bioeconomy transition. We then discuss the epistemic forms framework for discourse analysis and position it within interpretive policy analysis. In Understanding bioeconomy debates section, we delve into the major bioeconomy debates in greater detail in order to characterize it applying the epistemic forms framework. In Missing links: Discursive and practical forms of bioeconomy section, we diagnose the debate as largely lacking discursive and the practical knowledge forms. In Broadening of a bioeconomy debate section, we offer conceptual and practical advice to policy-makers to help inform the debate and promote a more democratic and participatory bioeconomy transition.

\section{Emerging bioeconomy transition: Headed towards polarization?}

The academic and policy literature on a bioeconomy has proliferated in the last decade including a number of review articles (de Besi and McCormick, 2015; Pfau et al., 2014; Schmidt et al., 2012; Staffas et al., 2013). We draw from this academic scholarship as well as the policy writings from international and country-specific perspectives of how a bioeconomy may be put in practice, and what challenges this may present to policymakers and other stakeholders. Most of the policy reports, national strategies and guidelines that we refer to come from the European Commission (EC), the Organization for Economic Cooperation and Development (OECD) and European Union countries, where some of the earliest discussions of a bioeconomy can be found. We complement these with experiences from the United States of America (US), Canada, Brazil and 
other countries. Perhaps the most outspoken proponent of a bioeconomy transition is the OECD (Goven and Pavone, 2015; Staffas et al., 2013). In its push towards a bioeconomy, the OECD has emphasized the role of economic growth and business opportunities, and underplayed the aspects of sustainability and resource availability (Staffas et al., 2013). The European Commission (EC) published a bioeconomy strategy in 2012 stating the need for new partnerships between industry, universities, the government and civil society (European Commission, 2012a). In addition to the efforts at EC level, a number of individual European Union member states have crafted their own bioeconomy strategies, such as Sweden, Finland, Germany and Belgium (de Besi and McCormick, 2015) as well as the US, Canada, Brazil and Malaysia (Langeveld et al., 2010; Staffas et al., 2013).

These actors view the bioeconomy transition as a means to fight the global climate change and growing energy insecurities, and to incentivize the slowed growth in the global financial crisis economy (Asveld et al., 2011). The economic stakes are high as the annual turnover of this sector in the European Union (EU) is about $€ 2.4$ trillion with more than 22 million people employed, approximately $9 \%$ of the total EU workforce (Danish Center for Strategic Research, 2012; Scarlat et al., 2015). A bioeconomy includes agriculture, food and beverage production, pharmaceuticals, agro-industrial products, fisheries and aquaculture, forest logging, wood-based industries, biomass for bio-heat and electricity production and industrial biotechnology products, such as enzymes and bio-plastics (Scarlat et al., 2015).

However, concerns about the potential negative 'side-effects' for society and the environment make the topic of a bioeconomy controversial. A number of international NGOs, environmental and bioethics related advocacy groups, and academics have opposed an uncritical transition to a bioeconomy (Asveld et al., 2011; Bang et al., 2009; ETC Group, 2000). A strongly worded report of ETC Group referred to the industry-driven bioeconomy as establishing 'biomassters', and a number of widely cited academic pieces discussed the extension of capitalism to life itself (e.g. Birch, 2012; Birch and Tyfield, 2012; Rajan, 2006). As Richardson (2012) pointed out, not all NGOs are outright critics of a bioeconomy. The World Wildlife Fund (WWF), for example managed to affect positive change through its cooperation with industry and governments (Richardson, 2012: 26). However, in some instances, WWF also criticized the large-scale investment in agriculture for biofuel production based on monoculture, 'land grabbing', and the conversion of forests into pastureland due to expansion of agriculture into the existing pastures (Bang, 2011).

Scholars have questioned the quick and almost universal embrace of a bioeconomy by governments, and emphasized the implicit assumptions and values promoted by a particular vision of a bioeconomy at the expense of alternative visions, such as conservation agriculture (Goven and Pavone, 2015). Butler et al. (2015) and Gamborg et al. (2014) raised concerns about the ethical and environmental implications of large-scale biofuel production. Concerns about the use of genetically modified organisms (GMOs) in both agricultural and industrial biotechnology have also surfaced (e.g. Levidow et al., 2012a). For example annual marches against Monsanto have mobilized thousands of people in 400 cities across 40 countries in 2015 alone (The Guardian, 2015). To what extent sentiments regarding GMO's or uncertainties about biofuels are likely to impact public opinion on a bioeconomy remains to be seen.

This stark divergence of views, the zeal with which the government-industry coalition in various countries promotes a bioeconomy on the one hand, and the backlash from environmental activists, critics of neoliberalism and non-governmental organizations on the other, suggests the emergence of a more polarized discourse (Levidow et al., 2012a, 2012b; Schmidt et al., 2012). Like earlier commentators, we observe that the current 
debate on a bioeconomy is fraught with controversies and deep disagreements on terms, the end-point of transition, the desirability and future effects on social and environmental systems (Birch, 2012; McCormick and Kautto, 2013; Pfau et al., 2014; Scarlat et al., 2015; Schmidt et al., 2012). These terms of the debate are, in part, determined by the framing of what a transition to a bioeconomy involves, and further contributes to the polarization of the discourse (Pierce, 2012).

Also aggravating the increasing danger of polarization of the bioeconomy discourse is the abstract nature of the concept, which makes mobilization of public engagement and discussion a challenge for policy-makers. We strive for a better understanding of the underlying causes for these dynamics through the application of the epistemic forms framework. The next section introduces our analytical framework, followed by an analysis of the deep ruptures or debates in the discourse briefly mentioned above.

\section{Epistemic forms for public policy}

To avoid polarization of the discourse and a resulting policy stalemate, we argue for an epistemic forms framework to help broaden the debate by emphasizing and grounding appreciation for multiple types of knowledge for designing and implementing good policies (Mukhtarov and Gerlak, 2014). Mukhtarov and Gerlak (2014) proposed a framework to distinguish between three epistemic forms, namely, prescriptive which is grounded in scientific-technical knowledge and has an imperative element to it; discursive, which is derived from values of and power relations among various stakeholders; and practical, which is based on the direct experience of implementing a policy concept in an interaction with multiple stakeholders, multiple values and worldviews, and in a particular context. They approach epistemic forms as relatively stable forms of knowledge with one or more of identifiable sources. These three epistemic forms are not mutually exclusive, and indeed, can refer to different types of knowledge that share attributes characteristic of more than one category. An obvious commonality between practical and discursive will call attention to the political realities of a given locality that may be highly relevant to policy decisions. The type of knowledge set forth in each category can be viewed as a way of anchoring complex information by calling attention to the source from which such knowledge emerges.

Initially applied in water governance, this framework has a broader appeal for public policy making and analysis (Mukhtarov and Gerlak, 2014). Multiple epistemic forms would promote the view of a bioeconomy beyond the scientific knowledge, and highlight considerations of ethics, intuition, values, emotions and indigenous and traditional knowledge (Feldman et al., 2006; Ingram and Endter-Wada, 2009). It builds on the ideas of 'metis', 'habitus', 'ways of knowing' and practice research in order to emphasize the distinct, context-dependent, pragmatic, and equally legitimate and valuable types of knowledge (Cook and Wagenaar, 2012; Dawes et al., 2009; Flyvbjerg, 2006; Scott, 1998; Weber and Khademian, 2008).

A cornerstone of the epistemic forms framework is the claim that all three epistemic forms are necessary for a policy to be legitimate, stable and ultimately effective (Flyvbjerg, 2006). Articulation of multiple epistemic forms in the public sphere and policy circles would allow for a more rounded discussion of not only 'how to get there', but also on 'where do we want to get' and 'what aspects of life are to be governed by competitiveness logic' in the first place (Flyvbjerg, 2001; Tenbensel, 2006). It is premised on a deliberative democratic ideal, in which a political and policy deliberation about interests and values is necessary (Dewey, 1916; Ingram and Rathgeb-Smith, 1993; Thiel et al., 2015). 
Table I. Prescriptive, discursive and practical ways of knowing in public policy.

\begin{tabular}{|c|c|c|c|c|}
\hline & Prescriptive & Discursive & Practical & Bio-economy illustrations \\
\hline Essence & $\begin{array}{l}\text { - Clear definitions of } \\
\text { problems and } \\
\text { solutions } \\
\text { - Prescription of } \\
\text { action } \\
\text { - "good practice" } \\
\text { examples }\end{array}$ & $\begin{array}{l}\text { - Values and ethics } \\
\text { - Symbolism in policy } \\
\text { - Power dynamics }\end{array}$ & $\begin{array}{l}\text { - Contextual } \\
\text { relevance } \\
\text { - Learning through } \\
\text { experimentation }\end{array}$ & $\begin{array}{l}\text { An economy which is less } \\
\text { dependent on fossil } \\
\text { fuels and provides } \\
\text { opportunities to } \\
\text { integrate industry, } \\
\text { agriculture and science } \\
\text { for 'green growth' }\end{array}$ \\
\hline $\begin{array}{l}\text { Form of } \\
\text { expression }\end{array}$ & $\begin{array}{l}\text { - Bio-economy } \\
\text { development plans } \\
\text { - Legislation, } \\
\text { - Participation guides } \\
\text { - Policy documents }\end{array}$ & $\begin{array}{l}\text { - UN reports } \\
\text { - Declarations, } \\
\text { guidelines } \\
\text { - Donor projects }\end{array}$ & $\begin{array}{l}\text { - Participatory } \\
\text { planning models } \\
\text { - Joint planning } \\
\text { approach } \\
\text { - Evaluation reports }\end{array}$ & $\begin{array}{l}\text { Policy reports, web-sites, } \\
\text { subsidy programs; } \\
\text { biorefineries where } \\
\text { multiple products are } \\
\text { derived from biomass }\end{array}$ \\
\hline Logic & $\begin{array}{l}\text { - Logic of } \\
\text { instrumentality }\end{array}$ & $\begin{array}{l}\text { - Logic of } \\
\text { appropriateness }\end{array}$ & $\begin{array}{l}\text { - Logic of } \\
\text { concreteness }\end{array}$ & $\begin{array}{l}\text { Instrumental and market- } \\
\text { based where the } \\
\text { private sector and } \\
\text { profit-making are the } \\
\text { key drivers; } \\
\text { technologies and } \\
\text { supportive } \\
\text { governmental policies } \\
\text { are asked for }\end{array}$ \\
\hline
\end{tabular}

Source: Based on Mukhtarov and Gerlak (2014).

Table 1 outlines the major differences between these three epistemic forms. These differences pertain to the source of knowledge claims, common outputs in which such knowledge manifests itself and the purpose of such claims in public policy. For the prescriptive form, the legitimacy of knowledge claims comes from science and technology. For the discursive, legitimacy stems from values shared in a society, ethical considerations or power issues, which make one or another claim more appropriate. By contrast, in the practical form, the source of legitimacy comes from experience, tacit knowledge and understanding the context. Similarly, though not exclusively, prescriptive forms are most often articulated in written form in policy documents, guidelines and legislation; discursive, in deliberative documents such as evaluation reports or public consultations; and the practical, in project documents, public hearing minutes and on the ground assessments. Finally, the prescriptive form aims at defining and resolving policy problems, the discursive is concerned with defining the direction of travel and desirability of the endpoint of policies, and the practical aims at the 'reality-check' in terms of contextual relevance and practical viability.

The epistemic forms framework fits well within the emerging tradition of interpretive policy studies. Policy arguments based on technical and analytical knowledge alone are insufficient to gain public legitimacy and achieve effective implementation. The cases of controversies over GMOs (Schneider and Ingram, 2007), biofuels (Butler et al., 2015; Knox and Marston, 2013: 314) and freshwater reclamation (Lejano and Leong, 2012; Lejano and Shankar, 2013) illustrate this point vividly. These cases demonstrate that unless value conflicts are considered and discussed publicly, policy stalemates may occur later on and be very difficult to resolve.

Policy actors need to ensure that various value-positions are debated openly and in this process of deliberation, some key policy options emerge as well as some common 
understanding on action (Arendt, 1970). As a result, policy work becomes an exercise in the ability to engage multiple epistemic forms in an open debate and to draw important lessons from such debates (Ingram and Endter-Wada, 2009). It is akin to what some commentators called 'collaborative capacity' building in attempts to conceptualize and resolve public policy issues (Weber and Khademian, 2008).

Various scholars in public policy have emphasized the shift away from positivism and the importance of interpretation of policy problems and solutions (Feldman et al., 2006; Yanow, 2009; Yanow, 1996). Our deployment of epistemic forms, however, is distinct from other evocations of value and knowledge pluralism. For example our work has been partly inspired by the innovative and path-breaking 'ways of knowing' approaches to public policy (e.g. Feldman et al., 2006; Ingram and Lejano, 2009; Lejano et al., 2013). These scholars contend that 'ways of knowing' are fluid and differ from one knowledge holder to another. These are necessarily embedded and situated types of knowing which emerge from various associations and translations between various stakeholders (Weber and Khademian, 2008). For us, unlike 'ways of knowing', epistemic forms are fixed to particular sources of knowledge claims, and are stable across agents and contexts. Once all three epistemic forms are brought together, purposefully and openly, 'ways of knowing' will start interacting with each other, if skilfully managed by public official and policymakers.

It is also important to distinguish epistemic forms from policy frames, as epistemic forms do not offer a perspective on a policy issue, or a particular linguistic or cultural angle (Dewulf et al., 2013). Rather, epistemic forms indicate the source of a knowledge claim. For example if OECD suggests that governments pursue bio-cascading in their transition to a bioeconomy, this knowledge claim is based on scientific and rational expertise and falls within the prescriptive form. In turn, if an NGO opposes bio-cascading on the premise that markets alone cannot decide on what biological resource is more valuable than another, such claim is a discursive one as it is based on values as a reference point. Thus, we utilize the epistemic forms framework for two purposes: first, to analyse the public and policy discourse on the subject of knowledge versatility in public policy; and second, to provide the normative push for the transition debate to include all three epistemic forms of a bioeconomy. In the next section, we analyse the bioeconomy discourse and demonstrate the value of the epistemic forms framework.

\section{Understanding bioeconomy debates}

Here we focus on what we see as three major debates that have emerged in the academic and policy literatures: (1) debate on the neoliberal underpinnings of a bioeconomy; (2) debate on the sustainability of a bioeconomy; and (3) debate on societal embedding of a bioeconomy. Other discussions include economic and production structures for the bioeconomy transition (Asveld et al., 2011), and emerging global governance of bio-products (Bastos Lima, 2012; Mukhtarov et al., 2014). However, we see the three abovementioned debates as most referenced and contentious. Our goal is to examine whether knowledge claims made in these three debates correspond to one or more epistemic forms.

\section{The debate on neoliberal underpinnings of bioeconomy}

Visions and definitions of what a bioeconomy may look like, and who may benefit from such a transition, dramatically diverge. First, the use of the term 'bioeconomy' as a desired destination of a transition underscores the economic aspects of the transition. As Paula 
and Birrer (2006) note, the term 'bio-society' may be more appropriate to emphasize the social, environmental and economic aspects of the transition which move beyond the boundaries of economic growth and acknowledges the spectrum of affected domains. This issue is currently debated in what can be called 'definitional politics' with various groups emerging with different definitions of a bioeconomy. While the narrow industry definition reduces the output of agriculture to the 'biomass' and emphasizes the functional characteristics of good food, broader definitions emphasize the role of farmers in rural development and cultural and traditional aspects of human-land relationships (Schmidt et al., 2012).

The European Community advocates policy language in their reports, and provide strategy and a set terms of discussion of a bioeconomy as a policy concept (Schmidt et al., 2012). Bioeconomy discussion is mostly based on the 'golden triangle' of the government, universities and industry that are perceived as the major drivers of a bioeconomy with civil society on the margins. A bioeconomy can be seen as an umbrella policy-term that has the effect of writing into consensus opposing views of stakeholders to provide policy language that is politically acceptable to diverse stakeholders (Conca, 2006; Walther, 1987).

One of the key models in making a bioeconomy work is bio-cascading (Schmidt et al., 2012). The Cologne paper authored by the European Commission (2007) proposed the biocascading model for a bioeconomy. While most references to bio-cascading specify the principle of sequential value extraction from biomass, such value is discussed in terms of global economy and markets (Scarlat et al., 2015). Bio-cascading is thus justified on the grounds of resource efficiency and cost-recovery (e.g. Keegan et al., 2013; Scarlet et al., 2015). Potential conflicts may arise between market value and possible intrinsic or bequest values of agricultural practices and biomass products. This is illustrated in Figure 1 below.

Such market-orientation and commodification of bio-mass has been criticized by some scholars as an extension of neoliberalism to nature, and life itself (Birch, 2012; Rajan, 2006; Levidow et al., 2012a, 2012b). Neoliberalism can be defined as 'mobilization of state power in the contradictory extension and reproduction of market (-like) rule' (Tickey and Peck, 2003: 166). From a neoliberal perspective, the value of resources is determined by their market value, while market-based instruments are often favoured to those of regulation. McAffee (2003) argued for the dangers of neo-liberalism in devising policies may disregard domestic agricultural sector, cultural autonomy and environmental conservation, which are

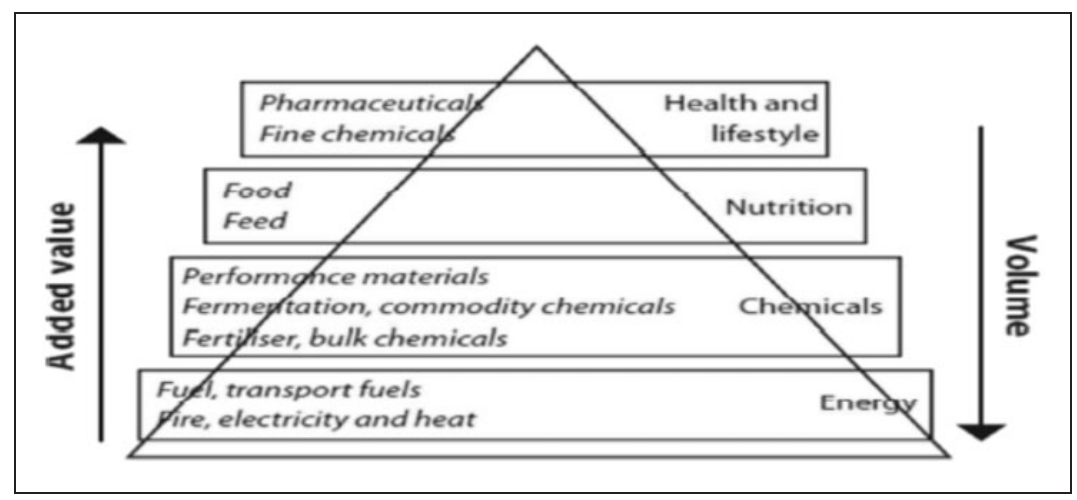

Figure I. The cascade model of a bio-refinery. Source: LNV (2007: 19). 
not easily judged in monetary terms in favour of other policies that are market-oriented and can be measured in monetary terms. In a similar vein, the ETC group (2010: 16), an international NGO, claimed that with the mainstream vision of a bioeconomy promoted by the governments, industry and international actors, economic and social structures may be erected to transfer biological resources into commercial commodities, such as 'electricity, biofuels, bulk chemicals, pharmaceuticals and textiles'. These considerations remain largely ignored and unexplored in the policy documents on bioeconomy.

\section{The debate on sustainability of a bioeconomy}

Many scholars and civil society organizations have questioned the sustainability of the transition to a bioeconomy, especially in the context of biofuels as an alternative energy source (Asveld et al., 2011). While the shift away from fossil fuels is welcome as a means of finding sustainable alternatives, mitigating climate change, and enhancing energy security, the sustainability outcomes of bio-fuels as well as integrated bio-refineries and further industrialization of agriculture remain unclear (Templer and van der Wielen, 2011).

Two divergent paradigms collide here: the agro-industrial vision for large scale production of crops for bio-fuels and bio-based materials and the agro-ecological vision which is based on the internal input and local production and integrated farming (Levidow et al., 2012a, 2012b). The potential benefits of an agro-industrial bioeconomy for rural development are often cited, however, these links are not easy to establish (Schmidt et al., 2012). For example a social programme run by the Brazilian government with an ambition to link rural development in the North-east of the country through linking smallholder farms with biodiesel producers has not reached its stated goals (Bastos Lima, 2012). The argument of some scholars that rural development may be enhanced through allowing the agricultural cooperatives run bio-refineries located in the rural areas still needs to be tested in practice (Paula and Birrer, 2006). Alternatively, agro-ecology as an attempt to deal with the environmental and social issues through agriculture could be an answer, but it has been under-valued in policy circles, arguably because it does not rely on emerging life science technologies and therefore does not promote economic growth (Birch, 2006; Levidow et al., 2012a).

Scholars have argued that sustainable development can be possible only if democratic requirements of public consultation and deliberation are satisfied, adding the political dimension to the otherwise technocratic focus of socio-technical transitions (Roseland, 2005). In the evaluation of bio-based production against sustainability criteria, attention is often focused on the reduction of greenhouse gas emissions and direct and indirect land use change (Ostergard et al., 2010), with growing calls for consideration of indirect land use change triggered by bio-fuels, such as deforestation and conversion of pasture land (Asveld et al., 2011). The Cramer Commission in The Netherlands put the issue of sustainability of a bioeconomy on the European agenda, but has not managed to get its criteria as a reference point more widely (Cramers and Koenders, 2008). Furthermore, the Roundtable on Sustainable Fuels, included eleven themes of sustainability that cover issues such as human and labour rights, and rural and social development (Ostergard et al., 2010). Life cycle analysis, scenario modelling and sustainability principles have all been discussed in relation to this debate (Ostergard et al., 2010) as ways of working towards greater certainty regarding the impacts of a bioeconomy.

A stand-alone publication in this regard is the review by The Nuffield Council on Bioethics, which developed an ethical framework consisting of six principles within which bio-fuels need to be considered in the contemporary zeal of achieving energy security and 
economic growth (Nuffield Council on Bioethics, 2011). These principles range from the welfare of bio-fuel producers and their employees to the impacts on the environment made by the production and consumption of bio-fuels (Nuffield Council on Bioethics, 2011). However, the lack of universally agreed sustainability criteria makes sustainability assessment a contextually dependent process to be applied on a case-by-case basis and relies on often voluntary schemes led by public-private partnerships.

Linked to the debate on sustainability of a bioeconomy are the policy controversies around biofuels, specifically the issue of 'land-grabbing', which for some evokes images of a new form of colonialism, as well as the long-standing and highly polarized debate of 'food versus fuel' (Asveld et al., 2011). Furthermore, in light of the complex links elucidated by integrated resource management discourse (Mukhtarov, 2008), scholars studying the environment suggested that land-grabbing is always also 'water and ecosystem' grabbing, extending therefore the potential negative impacts of bio-fuels (Mehta et al., 2012). Thus, the issue of sustainability of bio-fuels and a bioeconomy remains controversial. The nature of this debate, unlike the issue of neoliberal underpinnings of a bioeconomy, is more open and multiple perspectives are heard with regard to what counts as 'sustainable'. However, the unresolved nature of the debate and the stalemate in the fields of global governance of bioenergy shows the necessity to continue efforts of consensus-building at multiple levels regarding the nature and extent of acceptable trade-offs and identification of non-negotiable aspects.

\section{The debate on societal embedding of a bioeconomy}

This necessity to build consensus at the local level is paramount in our understanding of a successful transition to a bioeconomy. Public participation and societal embedding are important elements in socio-economic transitions and their legitimacy (Huitema and Meijerink, 2007). Some scholars argue for 'multi-stakeholder partnerships involving a broad range of civil society groups, including farmers, scientists, SMEs and consumers' in order to achieve a greater understanding and acceptance of the novel technologies (Schmidt et al., 2012: 60). These scholars have warned about the potential of a bioeconomy to reinforce the 'top-down' and technocratic decision making with the seeds of centralization as opposed to the co-production of knowledge and empowerment of farmers and decentralization (Sleenhoff et al., 2015). The European Commission's recent report on a bioeconomy further urges approaches that 'foster participation of researchers, end-users, policy-makers and civil society in an open and informed dialogue throughout the research and innovation process of a bioeconomy' (European Commission, 2012b: 8). However, it remains unclear how the actual practice of societal embedding of a bioeconomy should be implemented. While public deliberation is still clearly seen as one strong requirement of democratic policy process (Brugnach and Ingram, 2012; Mukhtarov, 2008), how such deliberation is going to be conducted in the case of a bioeconomy needs to be articulated in greater detail (Sleenhoff et al., 2015).

Two possible solutions for societal embedding have been put forth - participatory models and tools to engage stakeholders in joint problem definition and fact-finding; and the greater recognition of farmers as providers of services in a bioeconomy. Schmidt et al. (2012: 60) argued that farmers should be seen as 'providers of quality food, as managers of the agricultural eco-system and landscape and as contributors to rural development'. In this regard, a number of recent initiatives from the Netherlands deserve attention. The Constructive Technology Assessment and Interactive Learning and Action (ILA) approaches have been suggested to engage stakeholders in the development of emergent 
technologies in ecogenetics (Roelofsen et al., 2010). Furthermore, a series of public debates run in 2012 and entitled 'My 2030s' took place in The Netherlands providing an opportunity for members of the public to engage in a debate on a possible bio-based future (van der Berg et al., 2013). Sleenhoff et al. (2015) have sought to engage the public through affective means, and discuss a 'bio-based dinner' in the city of Delft in The Netherlands, where an abstract concept of a bioeconomy was made explicit in the bio-based nature of the food and surroundings of the meal, thus provoking interest, awareness and engagement with practical aspects of a bioeconomy.

While the importance of societal embedding and public deliberation is often mentioned in the policy circles in The Netherlands and European Commission, concrete mechanisms and commitment from industry and governments need to follow. An example of such change is the recently signed Dutch Bio-based Manifesto, which also included various civil society organizations, such as the International Union for Conservation of Nature and World Wildlife Fund (IUCN, 2015). More of such examples would be welcome.

\section{Missing links: Discursive and practical forms of bioeconomy}

Based on our review of three key debates on a bioeconomy, we find that a bioeconomy has been mostly framed as a prescriptive concept in the academic and policy scholarship which seeks to advance a particular vision of a bioeconomy which is technology-based, capital intensive and neo-liberal in how it determines the value of resources. We observe that the dominant focus has been on how to make a bioeconomy transition happen and not on whether such transition is necessary, and if so, what form it should take. The technocratic imaginaries of a bioeconomy 'utopia' are envisioned and promoted in the OECD and EC publications with little discussion of alternatives (Goven and Pavone, 2015), which is in line with observations of other commentators of this field (e.g. McCormick and Kautto, 2013; Schmidt et al. 2012).

In contrast, we find little discussion reflecting either bioeconomy as a discursive or a practical concept. As a discursive concept, a bioeconomy is not an objective sociotechnical transition which can be managed by a road-map and leads to a destination agreed by all stakeholders - rather it is a discourse that is influenced by the ideologies of neoliberalism and in which actors have incentives to produce knowledge and norms that favour them over others (Birch, 2006; Rajan, 2006). The open discussion with diverse stakeholders is necessary for a discursive epistemic form to emerge. As Norgaard (2011: 97) stated in her discussion of the climate change discussions '... when people get together and talk, a number of important things happen'. One of the major outcomes of such conversations and debates is the sharing of values, the creation of social norms and the building of a community.

By engaging with the discursive epistemic form, we ask the following questions: how can we make the underlying assumptions behind certain knowledge claims on a bioeconomy explicit? How can a policy scientist understand the diversity of values at play? How can these be communicated to all stakeholders in a manner that is meaningful to them? In such a way, the civil engagement for the transition to a bioeconomy is open-ended and includes encounters with civic society that does not engage the way the initiator of the engagement intended them to engage, incorporating the unexpected, eventful incidents and emotions' (Sleenhoff et al., 2015: 81).

The core of a practical epistemic form is recognition that practice gives rise to knowledge which is contextually dependent and could not be derived otherwise. This form of knowledge requires interaction and is developed in networks and collaborative spaces. Similar to tacit 
knowledge, it is developed through practice and experience and is usually hard to articulate analytically. The practical epistemic form does not emerge from the application of certain analytical principles in practice, but rather emerges from practice itself during the process of 'doing' (Weber and Khademian, 2008).

In the case of Europe, the European Commission recommends reinforcing policy interaction and stakeholder engagement include 'a bioeconomy panel' at the EU level, regular 'bioeconomy stakeholder conferences', and 'a bioeconomy observatory' (European Commission, 2012b). One recent initiative of the European Commission along these lines is the creation of the 'bioeconomy observatory', a Europe-wide database of research projects, investment, tools and practices in this sector of the economy (M'barek et al., 2014).

In addition, Langeveld et al. (2010) also addressed the practical epistemic form in four case studies: Brazil, Germany, The Netherlands and Canada, unearthing the great diversity of approaches united under the banner of a 'bioeconomy'. The case of Brazil underlines the importance of land use change and sustainability, to a great extent to satisfy the conscious energy importers in EU. In Germany, drafting consistent legislation regarding biofuels, biobased materials and chemicals is claimed as pivotal. In Canada, the use of residues and waste as stock for biofuels seems the most important for the transition, as well as and putting a bioeconomy on the agenda of all policy-makers and public. Malaysia, the second country in Asia after China to announce a national Bioeconomy Initiative, aims to utilize their substantial palm oil resources, a non-food raw material (Kamal, 2013). This diversity of approaches stresses the challenge of cataloguing and learning from the multitude of parallel practical efforts in making a bioeconomy happen.

Thus, there is a need for more case studies, stand alone and comparative, of a bioeconomy being put in practice and in various contexts (European Commission, 2012a, 2012b). Moving beyond ideas towards ideas in practice, and reflecting on the knowledge that emerges from practice is necessary for understanding what a bioeconomy means to the diverse actors, and how coordinated action forward can be taken. In the next section, we provide some possible strategies and directions for policy-makers to achieve versatility of knowledge in transitions.

While this analysis has shown that all three forms of epistemic knowledge have informed the policy debate, the relative weight and attention given to these three forms are vastly disparate. Isolated attempts to engage and educate the public are but a nod in the direction of the robust societal exchange that is necessary for meaningful engagement with the public such that both tacit knowledge and values can be credibly reflected in policy.

\section{Broadening of a bioeconomy debate}

From a policy perspective, we argue that a focus solely on the question of 'how' to make a bioeconomy transition happen is inadequate. Rather, a more democratic starting point would be examination of the possible trade-offs involved in transition to a bioeconomy and to what extent and whether a move to a bioeconomy is a viable and appropriate solution. By broadening the debate in this way, a community of practice can emerge.

We acknowledge that a successful socio-technical transition takes more than enlightened policy-makers; however, we focus on the necessary element of effective policy making which any transition demands. Indeed it requires commitment to shift the policy making culture away from a predominant focus on analytical knowledge, often coded in economics and management, to include considerations of discursive and practical dimensions of knowledgecreation. 
In order to aid policy workers in these tasks, we propose several potential directions in which policy-making process may be engaged in order to account for multiple epistemic forms. Our first set of recommendations is more conceptually oriented and geared towards new areas of research that are needed to help move beyond a polarized debate. Our second set of recommendations is more action-oriented recommendations for policymakers, practitioners and educators.

\section{Recommendations for scholars}

First, we suggest the need for policy scholars studying a bioeconomy to address issues of values, power and value conflicts and the importance of political and social context in research on transitions. Academic debates have agenda-setting and practical value. Policy workers make decisions based on a range of inputs, and mostly through certain interpretations of problems and solutions. Power is key to this process of interpretation (Flyvbjerg, 2001). In analysing the role of power in the framing of problems and definitions, political analysts need to ask such questions as 'who gains, and who loses, by which mechanisms of power?' (Flyvbjerg, 2001: 145).

Although some research around bioeconomy addresses the current political nature of framing a bioeconomy, this type of research remains under-represented in the technical literature on how to ensure a bioeconomy (Levidow et al., 2012a, 2012b; Schmidt et al., 2012). There are a growing number of initiatives at the level of individual countries, to create an environment for entrepreneurs to engage with a bio-based economy. For example, in The Netherlands, efforts are being made to bring parties together and build business ties (Hees et al., 2013); and improve the business environment for optimal use of biomass (Platform Landbouw, 2014).

However, further discussion is needed on what sort of a bioeconomy or bio-based future we want. This is important because scientific controversies around the sustainability of biofuels, their impact on land use planning and carbon dioxide emissions, are not resolved by science alone (Pierce, 2013). One can reasonably anticipate that the answer to some of these questions will emerge through an iterative process as not all contingencies can be fully foreseen. Nevertheless, engagement that leaves room for challenging certain assumptions would serve the building of a more democratic foundation for decisions regarding a bioeconomy.

At the heart of the potential polarization about a bioeconomy transition are diverging values and worldviews (Levidow et al., 2012a). The calls for societal embedding are lodged in the hope to make the transition more acceptable in terms of reflecting the values and multiple perspectives of the society and allowing for their interaction (e.g. Pierce, 2013). A constructive dialogue among stakeholders is possible only if we can move away from relying solely on the prescriptive format of the 'predict and prepare' paradigm onto more reflexive and deliberate policy practices (Forester, 2012). The approach of instrumental public engagement and 'management' of the debate and transition is helpful in getting the process started and outlining the major targets and challenges in this process. While useful as an action-oriented and pragmatic approach, it must be clear to policy makers that the complexity of the socio-technical transition to a bioeconomy requires deliberative processes, nuanced policy approaches, and respect for multiple ways of knowing.

Ultimately, the resolution of political tensions and value conflicts around a bioeconomy calls for 'advances in political process, rather than scientific research' (Sarewitz, 2004: 399). A major challenge today with the bioeconomy transition is not that it is political or politicized, but that it is not political enough. An initiative from the Dutch government 
illustrates a possible manner in which governments can politicize the subject and open it for a societal debate. On an interactive website, the Dutch state regulator for the environment provides information about the debates on bio-based economy in lay-person's language (Planbureau voor de Leefomgeving, 2014), thus contributing to a better informed and more meaningful debate in society. More initiatives of this sort are needed.

\section{Recommendations for policy makers}

In addition to these conceptually oriented recommendations, we offer a set of policy-oriented recommendations. First, for policy-making reforms to better account for multiple epistemic forms, there is a need for skilled intermediaries. We see intermediaries as individuals and groups who provide services for bridging divides between various sectors, disciplines and political cultures. These may be political consultants whose role is to negotiate between universities, governments, industrial groups and societal organizations. These also may be individuals hired by private companies or universities to assume roles in negotiation and communication like public relations experts. In addition, government actors and institutions may organize regular roundtables with various stakeholders to discuss positions in the open.

A good example of an intermediary, or a boundary organization, in the bioeconomy context is Tertium, an organization in The Netherlands that studies public opinion, facilitates workshops, and attempts to bridge society, science, government and industry (van der Berg et al., 2013). In 2012 and 2013, Tertium organized a series of public debates around the issues of bio-based future called 'My 2030' which brought together different stakeholders in discussions of possible bioeconomy scenarios in various aspects of lives experienced by the members of public (van der Berg et al., 2013). One interesting result of this project's study was that the public generally views 'biofuels' positively, but 'bio-energy' less so; and in general, the public (as represented by this small sample) remains largely unaware about the concept of a bioeconomy. This knowledge provides an important input into the strategy of those who target transition management. To be successful, such debates and workshops need to be ongoing as much more is gained through such networks and collaborations. The intangible effects of sharing knowledge, ways of knowing and building consensus are very important in such networks (Dawes et al., 2009).

Second, beyond advancing and promoting new, unique skill sets, intermediaries require policy space in which 'boundary work' can be performed and 'boundary experience' can emerge (Feldman et al., 2006; Guston, 2001; Weber and Khademian, 2008). Boundary organizations may provide a place in which scientists may keep their own integrity, yet engage with public policy actors (Lejano and Ingram, 2009). At the same time, boundary organizations may facilitate blurring of boundaries between multiple perspectives and allow for an easier policy compromise on controversial issues. Examples from the field of environmental governance suggest that such organizations can be effective (Schneider and Ingram, 2007).

However, such boundary organizations cannot be created for all public policy issues on an individual basis. A less formalized and efficient mechanism for intermediaries to enter and work to 'stitch together' different epistemic forms is also required. An example of a boundary organization for socio-technical transitions, including a bioeconomy, is the Rathenau Institute in The Netherlands, which bridges the divide between the general public, experts and policy-makers (The Rathenau Institute, 2014). Another transnational example is the Public and Regulation Initiative (PRRI), also hosted in The Netherlands, but with membership of public researchers from all over the world with a mission to connect 
life scientists, international regulators and the public (Public Research and Regulation Initiative, 2014).

Finally, there is a need for reflexive and deliberative practitioners and public managers in policy departments, NGOs, universities and companies, who 'can be more critical and selfcritical, more attuned both to how others claim and frame what they do and to the ways that our own claiming and framing can get us in trouble too' (Forester, 2012: 23). Such selfreflection is often challenging. Freeman (2007: 490), also in this vein, claimed that policy practitioners are typically narrowly trained in 'rational, scientific epistemology', and that this training needs to be complemented by others types of epistemology and knowledge. In the context of the bioeconomy transition, this would help train practitioners to move beyond the narrow focus on economic inputs for bioeconomy, and shift toward the non-economic inputs and the ability to interpret these inputs.

Hess and Adams (2002) argue that emphasizing such skills as listening, diplomacy and negotiation could enhance the capacity for integration of various types of inputs. For them, the management of policy paradoxes, puzzles and fragmentations is what constitutes the key aspect of the future policy work (Hess and Adams, 2002: 76). Such skills relate more to the processes by which policies are generated, legitimated and publicly valued as opposed to the tool-boxes of the knowledge itself.

We acknowledge the challenges of the boundary work of skilled intermediaries, such as the contested nature of knowledge claims, the embedded character of knowledge in particular experiences and contexts, differences in norms, ideologies and professional ethos among multiple stakeholders, among others (e.g. Dewes et al., 2009). The further research will identify and develop optimal implementation practices that capture these different types of knowledge and foster collaborative decision-making. Successful small scale public engagement has yielded important results (see e.g. Tertium, supra), but this endeavour is rarely systematic or truly representative. Moreover, in the case of a bioeconomy, the lack of familiarity of the public with this concept poses the additional challenge of engaging to educate and acquire better understanding of relevant societal sensibilities and values.

\section{Conclusions}

A bioeconomy can be known in three distinct ways - as a prescriptive concept with clear definitions and guidelines how to achieve it; as a discursive concept with contested and negotiated definitions, meanings, goals and effects of a bioeconomy; and as a practical concept which recognizes the inherent contingencies of the policy process and that a bioeconomy takes on specific meanings and forms in a specific context. Collectively, these three epistemic forms can help to broaden and prevent polarization of the bioeconomy debate.

In our analysis of three debates on a bioeconomy and multiple scholarly and policy literature, we find that a bioeconomy has been narrowly framed as a prescriptive concept in the policy debates and academic literature. As a result of this, there is far less discussion about the underlying values and the power relations at play. It may well be that discursive and practical epistemic forms are less suited to being analytically articulated, which may explain the domination of the prescriptive epistemic form in policy literature. This is regrettable considering the importance of public debates and engagement of multiple stakeholders for socio-technical transitions (Dewulf et al., 2009; Huitema and Meijerink, 2009).

In arguing for the place of multiple epistemic forms for informing the transition to a bioeconomy, we offer a set of recommendations for public policy. Our recommendation for 
scholars suggests the need for addressing issues of values and power, and the importance of political and social context in research on transitions, in studying a bioeconomy. For policymakers, practitioners and educators, we offer action-oriented recommendations that emphasize the importance of a nuanced skill set for policy-makers that can accommodate the importance of discursive processes which would better fit the needs of an interpretive policy analysis and policy-making. These recommendations highlight specialized intermediaries who may play a greater role in translating across epistemic forms in a policy space. It also includes the policy space for boundary organizations to facilitate bringing together different epistemic forms. Finally, policy-makers should ensure integration of approaches to engage in networking, reflexive practice and planning.

Policy making that acknowledges the equal standing of discursive and practical epistemic forms alongside the prescriptive one is more likely to result in sustainable and viable approaches. Our recommendations can provide a roadmap for the greater inclusion of the issues of values and power and attention to practice in policy circles.

\section{Acknowledgements}

The authors would like to thank Professor Patricia Osseweijer and Dr Annick Hedlund-de Witt for useful comments on earlier drafts of this article.

\section{Declaration of conflicting interests}

The author(s) declared no potential conflicts of interest with respect to the research, authorship, and/or publication of this article.

\section{Funding}

The author(s) disclosed receipt of the following financial support for the research, authorship, and/or publication of this article: This work was supported by Be-Basic Research Consortium Project TQSB53.

\section{References}

Arendt H (1970) On Revolution. New York: Viking.

Asveld L, van Est R and Stemerding D (2011) Getting to the core of the bioeconomy: A perspective on the sustainable promise of biomass. Report, The Rathenau Institute.

Bang J, Follér A and Buttazzoni M (2009) Industrial biotechnology: More than green fuel in a dirty economy? Exploring the transformational potential of industrial biotechnology on the way to a green economy. Report, Worldwide Fund for Nature report. Available at: http://www.bioeconomy.net/reports/files/wwf_biotech.pdf (accessed 11 December 2015).

Bastos Lima M (2012) An institutional analysis of biofuel policies and their social implications in developing countries: Lessons from Brazil, India and Indonesia. Report for United Nations Research Institute for Social Development.

Birch K (2006) The neoliberal underpinnings of the bioeconomy: The ideological discourses and practices of economic competitiveness. Genomics, Society and Policy 2: 1-15.

Birch K (2012) Knowledge, place, and power: Geographies of value in the bioeconomy. New Genetics and Society 31: 183-201.

Birch K and Tyfield D (2012) Theorizing the bioeconomy: Biovalue, biocapital, bioeconomics or ... what? Science, Technology, \& Human Values 8(3): 299-327.

Brugnach M and Ingram H (2012) Ambiguity: The challenge of knowing and deciding together. Environmental Science and Policy 15: 60-71. 
Butler C, Demski C, Parkhill K, et al. (2015) Public values for energy futures: Framing, indeterminacy and policy making. Energy Policy. Epub ahead of print. DOI: 10.1016/j.enpol.2015.01.035.

Conca K (2006) Governing Water: Contentious Transnational Politics and Global Institution Building. Cambridge: MIT Press.

Cook N and Wagenaar H (2012) Navigating the eternally unfolding present: Toward an epistemology of practice. The American Review of Public Administration 42: 3-38.

Cramers J and Koenders B (2008) Biobrandstof: ja, maar alleen als het duurzaam is. de Volkskrant, 25 March.

Danish Center for Strategic Research (2012) The Copenhagen declaration for a bioeconomy in action. Report.

de Besi M and McCormick K (2015) Towards a bioeconomy in Europe: National, regional and industrial strategies. Sustainability 7: 10461-10478.

Dewey J (1916) Democracy and Education. New York: Free Press, 1997.

Dewulf A, Brugnach M and Termeer C (2013) Bridging knowledge frames and networks in climate and water governance. In: Edelenbos J, Bressers $\mathrm{N}$ and Scholten $\mathrm{P}$ (eds) Water Governance as Connective Capacity. Farnham: Ashgate, pp. 229-247.

Dewulf A, Termeer C, Werkman R, et al. (2009) Transition management for sustainability: Towards a multiple theory approach. In: Poppe KJ, Termeer C and Slingerland M (eds) Transitions Towards Sustainable Agriculture and Food Chains in Peri-Urban Areas. Wageningen: Academic Publishers, pp. 25-51.

Dawes S, Cresswell A and Pardo T (2009) From "need to know" to "need to share": Tangled problems, information boundaries, and the building of public sector knowledge networks. Public Administration Review May/June.

Directorate General Research (2006) FP7 Theme 2: Food, agriculture, fisheries and biotechnology, 2007 work programme. Report, European Commission.

ETC Group (2010) The new biomassters: Synthetic biology and the new assault on the biodiversity and livelihoods. Available at: http://www.etcgroup.org/content/new-biomassters (accessed 02 June 2014).

European Commission. (2007) En Route to the Knowledge-Based Bioeconomy. Brussels: European Commission. Report, Cologne Paper.

European Commission (2012a) Bioeconomy newsletter, February, MEMO/12/97. Report, European Commission.

European Commission (2012b) Communication from the Commission to the European Parliament, the Council, the European Economic and Social Committee and the Committee of the Regions. Innovating for sustainable growth: A bioeconomy for Europe. Report, European Commission.

Feldman MS, Khademian AM, Ingram H, et al. (2006) Ways of knowing and inclusive management practices. Public Administration Review 66: 89-99.

Flyvbjerg B (2001) Making Social Science Matter. Cambridge: Cambridge University Press.

Forester J (2012) Learning to improve practice: Lessons from practice stories and practitioners' own discourse analyses (or why only the loons show up). Planning Theory \& Practice 13: 11-26.

Freeman R (2007) Epistemological bricolage: How practitioners make sense of learning. Administration \& Society 39(4): 476-496.

Gamborg C, Tegner H and Sandoe P (2014) Ethical and legal challenges in bioenergy governance: Coping with value disagreement and regulatory complexity. Energy Policy 69: 326-333.

Goven J and Pavone V (2015) The bioeconomy as political project: A Polanyian analysis. Science, Technology and Human Values 40(3): 302-337.

Guston DH (2001) Boundary organizations in environmental policy and science: An introduction. Science, Technology, \& Human Values 26: 399-408.

Hees E, Wolter E, Foluke QW, et al. (2013) Succes en falen van regionale projecten in de Biobased Economy. Deel B: Achtergrondrapport. Report for Wageningen University.

Hess M and Adams D (2002) Knowing and skilling in contemporary public administration. Australian Journal of Public Administration 61: 68-79. 
Huitema D and Meijerink S (2009) Transitions in water management: Positioning this book. In: Huitema D and Meijerink S (eds) Water Policy Entrepreneurs: A Research Companion to Water Transitions Around the Globe. pp. 3-23.

Ingram H and Rathgen-Smith ST (eds) (1993) Public Policy for Democracy. Washington, DC: Brookings Institution Press.

Ingram H and Endter-Wada J (2009) Frames and Ways of Knowing: Key Considerations for Policy Response to Climate Risk and Vulnerability. Human Dimensions of Global Environmental Change. Report, Berlin.

International Union for Conservation of Nature (IUCN) (2015) Manifesto on the bio-based economy. Available at: https://cmsdata.iucn.org/downloads/manifesto_bbe_english_02.pdf (accessed 03 November 2015).

Kamal M (2013) Bioeconomy - Sustainable alternative to fossil-based economy? Bioeconomy Malaysia. Report.

Kemp R, Loorbach D and Rotmans J (2007) Transition management as a model for managing processes of co-evolution. The International Journal of Sustainable Development and World Ecology 14: 78-91.

Kern F and Smith A (2008) Restructuring energy systems for sustainability? Energy transition policy in the Netherlands. Energy Policy 36: 4093-4103.

Keegan D, Kretschmer B, Elbersen B, et al. (2013) Cascading use: a systematic approach to biomass beyond the energy sector. Biofuels, Bioproduction and Biorefinery 7: 193-206.

Knox P, Marston, S (2013) Human Geography: Places and Regions in Global Context. Pearson, 80 pp.

Lakoff G (2002) Don't Think of an Elephant! Know Your Values and Frame the Debate: The Essneitla Guide for Progressives. White River Junction, VT: Chelsea Green.

Langeveld H, Sanders J and Meeusen M (eds) (2010) The Biobased Economy: Biofuels, Materials and Chemicals in the Post-Oil Era. London, Washington: Earthscan.

Lejano R and Ingram H (2009) Collaborative networks and new epistemic forms. Environmental Science \& Policy 12: 653-662.

Lejano R and Shankar S (2013) The contextualist turn and schematics of institutional fit: Theory and a case study from Southern India. Policy Sciences 46(1): 83-102.

Lejano R and Leong C (2012) A hermeneutic approach to explaining and understanding public controversies. Journal or Public Administration Research and Theory 22(4): 793-814.

Lejano R, Ingram H and Ingram M (2013) The power of narrative in environmental networks. Cambridge MA, MIT Press.

Levidow L, Birch K and Papaioannou T (2012a) Divergent paradigms of European agro-food innovation: The knowledge-based bioeconomy (KBBE) as an R\&D agenda. Science, Technology \& Human ValuesEpub ahead of print. DOI: 0162243912438143.

Levidow L, Birch K and Papaioannou T (2012b) EU agri-innovation policy: Two contending visions of the bioeconomy. Critical Policy Studies 6: 40-65.

Loorbach D and Rotmans J (2005) Managing transitions for sustainable development. In: Wiczorak AJ and Olshoorn X (eds) Industrial Transformation - Disciplinary Approaches Towards Transformative Research. Dordrecht: Kluwer Academic Publishers, pp. 187-206.

M'barek R, Philippidis G, Suta C, et al. (2014) Observing and analysing the bioeconomy in the EU Adapting data and tools to new questions and challenges. Bio-based and Applied Economics 3: $83-90$.

McAffee K (2003) Neoliberalism on the molecular scale. Economic and genetic reductionism in biotechnology battles. Geoforum 34: 203-219.

McCormick K and Kautto N (2013) The bioeconomy in Europe: An overview. Sustainability 5: 2589-2608.

Mehta L, Veldwisch GJ and Franco J (2012) Introduction to the special issue: Water grabbing? Focus on the (re)appropriation of finite water resources. Water Alternatives 5: 193-207.

Ministerie van Landbouw, Natuur en Voedselkwaliteit (LNV). (2007) Overheidsvisie op de bio-based economy in de energietransitie. Den Haag: Ministerie LNV. 
Mukhtarov F (2008) Intellectual history and current status of integrated water resources management: A global perspective. In: Pahl-Wostl C, Kabat P and Moltgen L (eds) Adaptive and Integrated Water Management: Coping with Complexity and Uncertainty. Heidelberg: Springer Verlag and Heidelberg GmbH and Co. KG, pp. 167-187.

Mukhtarov F and Gerlak A (2014) Epistemic forms integrated water resources management: towards versatility of knowledge. Policy Sciences 47: 101-120.

Mukhtarov F, Osseweijer P and Pierce R (2014) Global governance of biofuels: A case for publicprivate governance? Bio-based and Applied Economics 3(3): 285-294.

Norgaard K (2011) Living in Denial: Climate Change, Emotions, and Everyday Life. Cambridge: MIT Press.

Nuffield Council on Bioethics. (2011) Biofuels: Ethical Issues. London: Nuffield Council on Bioethics. Report.

Ostergard H, Markussen M and Meeusen M (2010) Challenges for sustainable development. In: Langeveld H, Sanders J and Meeusen M (eds) The Biobased Economy: Biofuels, Materials and Chemicals in the Post-oil Era. Bristol: Earthscan, pp. 33-49.

Paula L and Birrer F (2006) Including public perspectives in industrial biotechnology and the biobased economy. Journal of Agricultural and Environmental Ethics 19: 253-267.

Pierce R (2012) The ethics of reframing: The case of the biofuels debate. In: Bucchi M and Trench B (eds) Public communication of science and technology conference.

Pierce R (2013) Bridging current issues in science and society. Biotechnology Journal 8: 875-877.

Planbureau voor de Leevomgeving (2014) Biomassa: wensen en grenzen. Available at: http:// infographics.pbl.nl/biomassa/ (accessed 20 July 2014).

Platform Landbouw (2014) Succes en falen van regionale producten van agrarische ondernemers in de Biobased Economy. Deel A: Advies. Platform Landbouw, Innovatie \& Samenleving: Platform Landbouw, Innovatie \& Samenleving. Report.

Pfau S, Haggens J, Dankbaar B, et al. (2014) Visions of sustainability in bioeconomy research. Sustainability 6: 1222-1249.

Public Research and Regulation Initiative (2014) The Public Research and Regulation Initiative. Available at: http://www.prri.net/category/news/ (accessed 5 May 2014).

Rajan K (2006) Biocapital: The Constitution of Postgenomic Life. Durham: Duke University Press.

The Rathenau Institute (2014) The Rathenau Institute. Available at: http://www.rathenau.nl/en.html (accessed 2 August 2014).

Richardson B (2012) From a fossil-fuel to a biobased economy: The politics of industrial biotechnology. Environment and Planning C 30(2): 282-296.

Roseland M (2005) Towards Sustainable Communities: Resources for Citizens and Their Governments. New Gabriola, BC: New Society Publishers.

Roelofson A, Broerse J, de Cock Buning T, et al. (2010) Engaging with future technologies: how potential future users frame ecogenomics. Science and Public Policy 37(3): 167-179.

Sarewitz D (2004) How science makes environmental controversies worse. Environmental Science \& Policy 7: 385-403.

Scarlat N, Dallemand JF, Monforti-Ferrario F, et al. (2015) The role of biomass and bioenergy in a future bioeconomy: Policies and facts. Environmental Development 15: 3-34.

Schmidt O, Padel S and Levidow L (2012) The bioeconomy concept and knowledge base in a public goods and farmer perspective. Bio-based and Applied Economics 1: 47-63.

Schneider A and Ingram H (2007) Ways of knowing: Implications for public policy. In: Annual meeting of the American Political Science Association. 29 August-2 September, Chicago.

Scott J (1998) Seeing Like a State: How Certain Schemes to Improve the Human Condition Have Failed. New Haven, CT: Yale University Press.

Sleenhoff S, Landeweerd L and Osseweijer P (2015) Bio-based society by including emotions. Ecological Economics 116: 78-83.

Staffas L, Gustavsson M and McCormick K (2013) Strategies and policies for the bioeconomy and bio-based economy: An analysis of official national approaches. Sustainability 5: 2751-2769. 
Templer R and van der Wielen L (2011) Biorenewables, the bio-based economy and sustainability. Interface Focus 1: 187-189.

Tenbensel T (2006) Policy knowledge for policy work. In: Colebatch H (ed.) The Work of Policy: An International Survey. Lanham: Rowman and Littlefield Publishers, pp. 199-217.

The Guardian. (2015) Tens of thousands march worldwide against Monsanto and GM crops. The Guardian 24 May. https://www.theguardian.com/environment/2015/may/24/tens-of-thousandsmarch-worldwide-against-monsanto-and-gm-crops.

Thiel A, Mukhtarov F and Zikos D (2015) Crafting or designing? Science and politics for purposeful institutional change in social-ecological systems. Environmental Science \& Policy 53(Part B): 81-86.

Tickey A and Peck J (2003) Making global rules: Globalization or neoliberalization? In: Peck J and Wai-Chung Yeung H (eds) Remaking the Global Economy London: SAGE Publications Ltd, pp. $163-181$.

van der Berg N, Hulshof M and van der Veen M (2013) My 2030s: Burgers over de biobased economy. Report, Tertium.

Walther O (1987) Against idealistic beliefs in the problem-solving capacities of integrated resource management. Environmental Management 11: 439-446.

Weber E and Khademian A (2008) Wicked problems, knowledge challenges, and collaborative capacity builders in network settings. Public Administration Review 2008: 334-349.

Yanow D (1996) How Does a Policy Mean? Interpreting Policy and Organizational Actions. Washington, DC: Georgetown University Press.

Yanow D (2009) Ways of knowing: Passionate humility and reflexive practice in research and management. The American Review of Public Administration 39(6): 579-601.

Farhad Mukhtarov is a researcher at Copernicus Institute of Sustainable Development, Utrecht University and an adjunct senior research fellow at Lee Kuan Yew School of Public Policy, National University of Singapore. Farhad's research focuses on environmental governance at the intersection of the global, national, and local levels, with a particular interest in water governance.

Andrea Gerlak is an associate professor in School of Geography and Development and associate research professor with the Udall Center for Studies in Public Policy at the University of Arizona. Her research addresses the human dimensions of global environmental change with a focus on institutions in water governance.

Robin Pierce is a senior lecturer in Law at Brunel University London, School of Law. Her research addresses legal, policy, and ethical issues regarding innovations in the life sciences, primarily for biomedical applications. She also conducts research in the area of data protection and privacy broadly and specifically in the context of health and clinical research. 